\section{EXISTENCE AND SUCCESSION OF AGRICULTURAL LAND AROUND BANGKOK}

\section{Pijak Hinjiranan ${ }^{1}$ \\ Suwattana Thadaniti, and \\ Siriwan Silapacharanan ${ }^{2}$}

\begin{abstract}
Covering more than 200,000 rai, agricultural land around Bangkok has been put to various uses for more than 300 years. The types of plants grown there have changed over time, and some planting is close to communities. As a result, points worth studying are how this land still exists, what causes the planting of new plant species to replace existing ones, which species can thrive in a suburban area like this, and which species should be promoted in this area. The study is conducted by means of comparing the location of this area with the theory of locating ideal agricultural land, the theory of succession and the existence of communities. The findings will benefit planning to conserve urban green areas.
\end{abstract}

${ }^{1}$ Ph.D. candidate, Department of Urban and Regional Planning, Faculty of

Architecture, Chulalongkorn University, Thailand.

${ }^{2}$ Associate Professors, Department of Urban and Regional Planning, Faculty of Architecture, Chulalongkorn University, Thailand.
The study reveals that the existence of this land results from economic conditions, types of plants, and the environment. The sequence of agricultural existence ranges from orchids, grass land, kaffir lime vegetables, aquatic plants, flowering plants, paddy fields, and oranges to livestock Traditional orchards cannot survive because of economic factors.

The pattern of agricultural succession is moving out of the urban center. Paddy fields and livestock are at the outer edge of this land because of low turnover. However, the area for growing orchids can be expanded in every direction. Elderly labor and labor from the outskirts of Bangkok support the existence of this area. In addition, there are fewer pests in this area so it is ideal for planting pesticide free vegetables. To maintain the existence of this land, it is recommended that bypasses be controlled or adapted so that they are not connected to this area. The disposal of sewage from residences should be strictly controlled. Rivers and other water resources should be revived. The agricultural land should be promoted as a recreational place or a tourist attraction. An intervention should be imposed in agricultural land adjacent to the city such as the agricultural areas in Bang Ramat and in Saphan Sung.

\section{Introduction}

Like the capitals of other developing countries in Southeast Asia, Bangkok is a capital which has grown rapidly and is now invading fertile agricultural areas. Since such areas lie in the tropical zone, there is a diversity of plant species. Some species such as kaffir lime, durian and mango produce high-quality fruit due to the specific combination of soil, water, and climate. According to the Office of Agriculture in 
Bangkok, the agricultural land around Bangkok can be classified into 7 types: paddy field, orchard, vegetable plantation, horticulture areas, livestock areas, fishery and lawngrass planting area. They are different in terms of raising method, site and level of existence.

\section{Situation}

The following summarizes major events affecting the agricultural adaptation since the early Rattanakosin Period.

Table 1: Major events affecting agricultural adaptation

\begin{tabular}{|c|c|c|}
\hline Period & Year & Situation \\
\hline Traditional agriculture & Before 1874 & $\begin{array}{l}\text { Residents around Bangkok were agriculturalists, } \\
\text { growing rice by transplanting rice seedlings until } \\
\text { 1931. However, there were some areas for planting } \\
\text { left so agriculturalists grew rice by sowing rice seeds } \\
\text { so the seeds covered a larger area. }\end{array}$ \\
\hline $\begin{array}{l}\text { Bowring Treaty } \\
\text { (King Rama V-VII) }\end{array}$ & $1871-1914$ & $\begin{array}{l}\text { Rice was first grown for export in } 1930 \text {. After that } \\
\text { there were fewer rice fields and droughts occurred. } \\
\text { The government abolished collection of fees for rice } \\
\text { fields. }\end{array}$ \\
\hline World War II & 1950 & $\begin{array}{l}\text { Rice became a major export product and cashcrops } \\
\text { were introduced. }\end{array}$ \\
\hline $\begin{array}{l}\text { Green Revolution (National } \\
\text { Socio-economic Development } \\
\text { Plan 1) }\end{array}$ & From 1961 & $\begin{array}{l}\text { Rice growing was considered an industry and was } \\
\text { aimed for expansion. Cashcrops were promoted and } \\
\text { forests were cleared to make way for agriculture. }\end{array}$ \\
\hline $\begin{array}{l}\text { Economic Depression I } \\
\text { (Coincided with National } \\
\text { Socio-economic Development } \\
\text { Plan 5) }\end{array}$ & $1982-1986$ & $\begin{array}{l}\text { There was a large income gap of } 8 \text { times between the } \\
\text { agricultural sector and other sectors. Forest clearing } \\
\text { was discontinued. }\end{array}$ \\
\hline Soap Bubble Economy & $1987-1992$ & $\begin{array}{l}\text { Due to the Plaza Accord ratified by G5, the dollar } \\
\text { was devalued. As a result, the non-agricultural } \\
\text { sectors expanded and Thailand became a NICS. The } \\
\text { income of the agricultural sector was } 12 \text { times less } \\
\text { than other sectors. There was an increase in tourism } \\
\text { and the capital was growing dramatically. }\end{array}$ \\
\hline Economic Depression II & $1995-2000$ & $\begin{array}{l}\text { The intrusion into suburban agricultural land was } \\
\text { stagnant. }\end{array}$ \\
\hline Economic Revival - At Present & $2001-2006$ & $\begin{array}{l}\text { Contract Farming has been proliferating and GMOs } \\
\text { have been planted. The construction area has been } \\
\text { expanded at a regular pace. }\end{array}$ \\
\hline
\end{tabular}


The land surrounding Bangkok was primarily used as paddy fields, when the capital was relocated from the west side of the Chao Phraya River to the east side in 1782. The capital has expanded quickly and invaded the paddy fields in the East while there has been agricultural adaptation and succession. Betelnut palms were found mostly in orchards in this area which first appeared during the Ayudhaya Period (before 1678). In early 1871, more varieties of plants were grown there. however, after 1950, the amount of agricultural land decreased. In 19901991 , it decreased dramatically because the land was needed for housing whose supply was more than the real demand. There was no further decrease in agricultural land due to the economic crisis from 1995 to 2000 (as shown in Table 1).

Seven activities have been conducted on the agricultural land around Bangkok, and the area for doing these activities has been reduced. The seven activities are rice growing, fruit tree growing, vegetable growing, flowering plants growing, livestock raising, fish farming and lawngrass nursery. The paddy fields on the east side of the river totaled 200,000 rai in 1989 but in 2000 it was reduced to 50,000 rai even though it increased in 1999 because rice fetched a good price. The land for growing fruit trees on the west side decreased from 24,000 rai in 1990 to 1,000 rai in 2000 especially in Bang Khun Thian District. Generally, the land for growing vegetables decreased but it increased to 1,200 rai in 2000 in Bang Khae District.
In general, the land for growing flowering plants decreased but it increased to 2,000 rai in 2000 in Bang Bon District, Chom Thong District, Bang Khun Thien District, and Phasi Charoen District which are close to urban areas. Animal raising almost vanished in 1999 but the area for animal raising increased on the east side to 1,000 rai in 2000-2001 because the price for beef was good. The area for fish farming on the east side around Bang Khun Thien increased to 20,000 rai and on the west side as well. Lawngrass has been grown on the east side especially in Khlong Sam Wa District and Lat Krabang District, covering 3,500 rai since 2000 .

Suburban agricultural areas gradually decreased by 9.68 percent from 1987-1994 (Pasma, 1993). In 1989 , the total amount of agricultural land was 450,473 rai and in 2001, the agricultural land in 27 districts around Bangkok was 215,536 rai.

The reduction in agricultural land is the results of economic and urban development activities. However, rules and regulations have been issued to conserve this land such as the Plant Genes Conservation Program initiated by the King compensation for agriculturalists suffering from floods, designation of green strips in the city plan of Bangkok, and laws controlling the construction of buildings. The green strips were in the urban and rural policy of the $5^{\text {th }}$ National Socio-economic Development Plan (1982-1986) and in the $2^{\text {nd }}$ Bangkok Development Plan. In 1999, the green strips were incorporated in the city plan of Bangkok. In the 2006 City Plan of Bangkok, the green strips were changed into residential zones due to community expansion. 
Figure 1 : Agricultural areas of Bangkok Metropolitan Area between 1989-2004

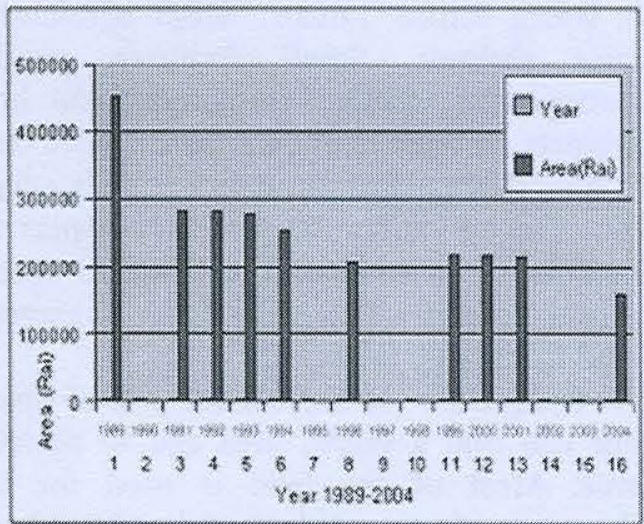

Sources : 1) Bangkok Agricultural Extension Office 2) Bangkok Social Development Office

Figure 2: Two different agricultural land types on each side of the ChaoPraya River in 1896

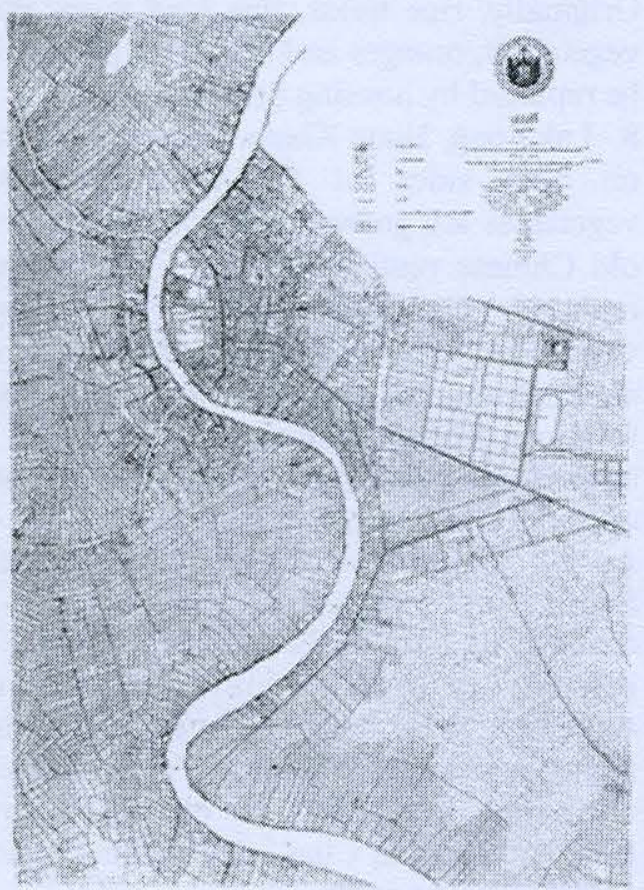

Source : Department of Military Maps

\section{The study}

This study aims to conserve suburban agricultural land for each activity. The theory of urban center, agricultural location and ecological and sustainable succession are used to analyze changes, land use and factors concerning sustainability and existence. A survey of locations, in-depth interviews, pattern analysis and integration of qualitative data and quantitative data are used to obtain results. The studied land is divided largely into 2 parts: inner and outer suburban areas on the east side of Bangkok and inner and outer suburban areas on Bangkok's west side. They are further divided into 22 enumerated districts according to geographical information about land use in Bangkok in 2002. Each district represents a studied area.

\section{Agricultural Land Next to the West of Bangkok}

1. Bang Ramad. This area grows such wellknown fruit trees as coconut, durian, sapodilla, mangosteen, custard apple, mango, yellowsentol, pomelo, and jackfruit. However, agriculturalists fetch more money from kitchen plants especially kaffir lime. Thai and Chinese agriculturalists either own or rent the land. Since the land's ecologically varied, there are few pests. In addition, the kaffir lime cannot be grown well in outer Bangkok.

2. Bang Prom. Once suitable for fruit trees, this area is crowded with canals and small aqueducts. At present, kitchen plants such as kaffir lime and screw pine are grown in addition to other plants. Most of the aqueducts are still useful for the agriculturalists who sometimes are faced with problems caused by construction workers' children who trespass on their land. 
3. Bang Chuek Nang. Housing has slowly expanded into the area, which once grew primarily coconut, betel palm, betel vine, mango and banana. At present, both older and younger agriculturalists earn most from orchids sold in the country. However, they are faced with water pollution and no easy access to their land. To solve water pollution, they use water from the aqueduct for their plants.

4. Bang Wa - Phasi Charoen. Once suitable for coconut, betel palm, betel vine, banana, rose apple, native lychee and orange, this area is now marsh land which is suitable for water plants such as water mimosa, lotus and morning glory. In 2004 Kala Prapreuk Road was constructed through this area. Some part of the land which was for agriculture has been filled in to make way for housing estates. The agriculturalists here are middle-aged people. Bang Kae Market and Wat Sai Market are local markets for water plants around here.

5. Land Bordering Thung Khru, Chom Thong, Bang Mod and Bang Khun Thian. It is equipped with canals and aqueducts. Above it is a ring road. Coconut, banana, mango, rose apple, jackfruit, custard apple and string bean are grown together. There are also flowering plants and a few duck farms. Oranges and orchids are on the south of Bang Mot. Shrimp farms are invading this area.

\section{Agricultural Land to the West of Bangkok}

6. Bang Khun Thian. Most agriculturalists raise shrimps. Small factories, residential communities, garden restaurants and housing projects are seen here and there. Since the land is low, raising shrimps naturally does not cost a lot. The agriculturalists are land owners whose land has been handed down by their ancestors. A green conservation program helps protect this land from large factories.

7. Bang Bon. In the central part of this land, one can find a vacant area and an agricultural area. Most of the land is used for raising flowering plants. White champaka is planted most, followed by Crown flower. They are popular because they can fetch a reasonable sum of money and can be grown on a small plot of land. The owners are old-aged agriculturalists with little education. However, there are some younger agriculturalists doing farming. Originally, rice fields, this land is for planting vegetables, oranges and flowering plants. It may be replaced by housing projects.

8. Lak Song, Nong Kham. Housing projects are on both sides of the road. Orchids and vegetables are grown. Most agriculturalists are old Chinese renting the land. Vegetables have replaced rice and orchids have replaced vegetables. The same kind of plant is grown in the same area for the convenience of customers. 9. Klong Thawi Wattana. There are a lot of banana plantations and vegetable gardens in addition to a few guava gardens and rice fields. As for substitution, the rice fields have been turned into vegetable gardens and then changed into orchid farms. This land has been intensively used. Sometimes, however, the succession is not in that order since orchids fetch higher prices and orchid farms are on the route connecting Bang Kae, an old orchid growing area, and Nakhon Chai Sri and Bang Lane, new orchid growing areas. 


\section{Existence and Succession of Agricultural Land around Bangkok}

Figure 3 : Agricultural numeration districts on both sides of Bangkok as sample for the study

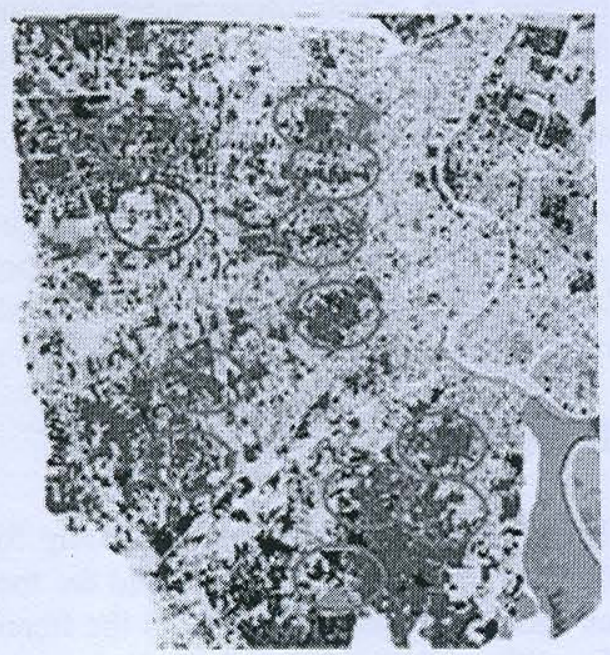

Western BMA

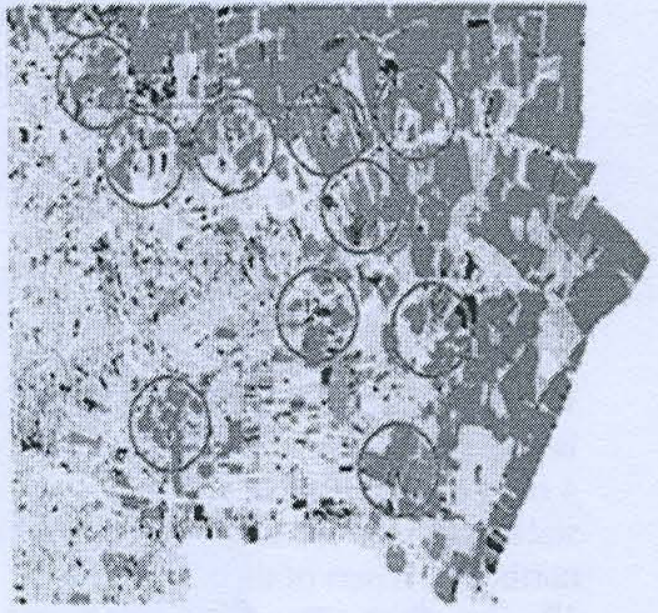

Eastern BMA
10. Thawi Wattana-Thammasala. Vegetable farms and orchid farms cover most of the land in addition to housing projects and goods transferring sites. The rice fields are changed into vegetable farms and then to orchid farms. Those who do vegetable farms are middle-aged agriculturalists, most of whom own the land, while new orchid farmers are younger and better educated.

\section{Agricultural Land Next to the East of Bangkok}

This land comprises 11. Wat Lad Bua Khao, Sapan Sung, 12. Khan Na Yao, Bang Chan, 13. Tha Rang, Bang Khaen and 14. Sai Mai, Oa Nguen.
They share some common characteristics as follows:

Most of the land is used for growing rice 2-3 times a year and most farmers both Bhuddist and Muslim rent about 30-40 rai of land. They once owned the land but later sold it so they have to rent their own land to do rice farming. Some farmers also raise fish and grow other plants. The farmers earn extra money by selling birds and field mice. The farmers are the ones who determine the existence of the rice fields; however, they are faced with theft, garbage dumping, polluted water released from housing estates and complaints about burning rice fields. Other agricultural plants are not worth growing because of the quality of soil and water. 
Agricultural Land to the East of Bangkok

15. Sai Kong Din Tai. Raising cattle is a supplementary activity because vacant areas can be useful and cattle dung can be used as a fertilizer.

16. Sai Kong Din. Since it is a water catchment area, it is flooded during the rainy season.

17. Ku Fung Neu. Muslim communities inhabit the areas along the San Saep Canal and grow many kinds of plants.

18. Bang Chan. Only the Muslims do lawngrass nursery and each family owns 4 rai. Lawngrass nursery requiring clean water and most of its labor is from the northeastern part of the country.

19. San Saep, Beung Khwang Road. There are nurseries for organic vegetables and a chicken factory among rice fields.

20. Lum Pak Chee Lum Khaek. Most of the land is covered by rice fields followed by fish ponds.

21. Tup Yao. It is a Mon Community and some locals are hired to grow rice. Some Taiwanese asked to rent a piece of land to raise orchids.

22. Lad Krabang. Groups of farmers rent hundreds of rai to grow rice and a lot of machines are used for this purpose. The most distinguished agricultural activity among Buddhists and Muslims is growing rice. The farmers either own or rent the rice fields and the size of the rice fields range from 30-40 rai or smaller. Some farmers have fish ponds. Some of their children do other activities such as operating a factory and they hire the locals to help them in the factory. Some older farmers used to work in the city. Farmers from other areas have to rent rice fields. The problems are birds eating the rice seeds in the fields and garbage and construction materials dumped in the fields. The farmers also agree that proper water management should be carried out to solve a lack of water during summer.

According to the study, each type of agriculture groups in cluster. On the west side, there are a lot of changes while the east side has witnessed more vegetable farms and fish ponds.

\section{Issues}

The findings are analyzed according to 1) the order of existence, 2 ) the site and the movement of agricultural activities and 3) the financial aid for each activity.

\section{The Order of Existence}

Based on the concepts of community existence, sustainability and community economy, the following 3 factors should be taken into consideration. They are economic factors, farmers' characters, and physical and environmental factors. Coupled with knowledge about agricultural practices, these three factors can be subdivided as follows:

Economic factors include investment and returns, the features of land, the specific features of agricultural activity and product management. The first item covers building investment, income from agricultural activities, supplementary income, the prices of produce and the projected export chance. The second item covers the size of the farm, the size of the land per head, the expansion of the farm and the type of land owning. The third item covers the time each plant takes before harvest, the 
uniqueness of the plant, and the risk of damage. The fourth item covers the sale of products, the quality grading of products or product process, the type of market and sustainable agriculture. Farmers' characters comprise farmers' characters and support. The first item covers their time off, age, educational background, and their relationship with their relatives. The second item covers agricultural promotion, new inventions or special technologies. Physical and Environmental factors include ecological systems which cover ecological conditions, benefits from the city or from other activities around the farm, the effects of urban environment and recreational use.

The following table presents the data analyzed according to the three above mentioned factors. Conclusion of the analysis is based on the three factors.
Based on the three factors, the order of existence rank from high to low: flowering plants and orchids, lawngrass, kitchen vegetables; kaffir lime, vegetable farms, aquatic animals, screw pine, white champaka, crown flower, and jasmine, rice, oranges, water-mimosa, and livestock.

Orchids and lawngrass are distinctive in terms of economic stability. Farmers' characters attract the younger generation to carry on this occupation. Kaffir lime is environmentally outstanding because it benefits both suburban and urban residents. As a result, it should be grown near the city as it has been. Watermimosa and livestock rank low in terms of existence. Rice has fetched higher prices lately and rice fields have a better chance of existence if they are outside the city.

Table 2: The Total Marks of Factors for the Order of Existence of Each Agricultural Activity

\begin{tabular}{|c|c|c|c|c|c|c|c|}
\hline \multicolumn{2}{|c|}{ Economic Factors } & \multicolumn{2}{|c|}{ Farmer Factors } & \multicolumn{2}{|c|}{ Environmental Factors } & \multicolumn{2}{|l|}{ Total Order } \\
\hline \begin{tabular}{c|} 
Type \\
\end{tabular} & Mark & \begin{tabular}{c|} 
Type \\
\end{tabular} & Mark & \begin{tabular}{c|} 
Type \\
\end{tabular} & Mark & \begin{tabular}{c|} 
Type \\
\end{tabular} & Mark \\
\hline Orchids & 3.846 & Orchids & 3.500 & Kaffir lime & 3.250 & Orchids & $\begin{array}{c}10.34 \\
6\end{array}$ \\
\hline Lawngrass & 2.615 & Vegetables & 2.833 & Screw pine & 3.000 & Lawngrass & 7.948 \\
\hline Aquatic animals & 2.462 & Kaffir lime & 2.333 & Orchids & 3.000 & Kaffir lime & 7.890 \\
\hline Kaffir lime & 2.307 & Lawngrass & 2.333 & Lawngrass & 3.000 & Vegetables & 7.237 \\
\hline $\begin{array}{l}\text { White champaka, } \\
\text { Crown flower, } \\
\text { Jasmine }\end{array}$ & 2.307 & Water-mimosa & 2.167 & Aquatic animals & 2.750 & Aquatic animals & 7.212 \\
\hline Screw pine & 2.231 & Orange & 2.167 & Rice & 2.750 & Screw pine & 6.814 \\
\hline Orange & 2.231 & Aquatic animals & 2.000 & $\begin{array}{l}\text { White champaka, } \\
\text { Crown flower, } \\
\text { Jasmine }\end{array}$ & 2.500 & $\begin{array}{l}\text { White champaka, } \\
\text { Crown flower, } \\
\text { Jasmine }\end{array}$ & 6.807 \\
\hline Water-mimosa & 2.154 & $\begin{array}{l}\text { White champaka, } \\
\text { Crown flower, } \\
\text { Jasmine }\end{array}$ & 2.000 & Vegetables & 2.250 & Rice & 6.750 \\
\hline Vegetables & 2.154 & Rice & 2.000 & Water-mimosa & 1.750 & Orange & 6.148 \\
\hline Rice & 2.000 & Screw pine & 1.833 & Orange & 1.750 & Water-mimosa & 6.071 \\
\hline Livestock & 1.538 & Livestock & 1.833 & Livestock & 1.500 & Livestock & 4.871 \\
\hline
\end{tabular}




\section{The Site and Movement}

According to the statistics about agricultural land in Bangkok, the survey of land use, interviews with agriculturalists in each studied area, aerial photographs and satellite data in the past 30 years, rice fields have been moving away from Bangkok. In general, some of them have been transformed into residential areas especially on the east side while some on the west side have been transformed into other kinds of agricultural activities. As for orchards, traditional well-known fruit trees grown from Bang Kruay to Bang Khun Tian, agricultural land next to the west of Bangkok, cannot fetch a lot of money as they used to. As a result, they are replaced by kitchen vegetables, kaffir lime, screw pine, bananas and orchids or housing. Some areas in the south of Bangkok are flooded so they have been changed into areas for raising aquatic plants like water-mimosa, lotus and morning glory. Originally vegetable farms were on the outside of orchards. They were in Klong Bua, Taling Chan and Klong San Chao Ban Suan Dan. Now they are replacing rice fields in Tawee Wattana, Bang Khae and Nong Kham. Flowering plants on the west can be divided into orchid farms whose planting areas are expanding around Bang Kae and penetrating into Bang Wak, Phasi Charoen, Chom Thong, Bang Mod, Nong Kham, Tawee Wattana, Phuttamonton, Nakhorn Chaisri and Bang Lane. White champaka, Crown flower, and jasmine are mostly grown in Bang Bon. They replace rice. Cows and goats are raised on the east side. However, this causes problems for the surrounding residential areas such as foul smelling dung, polluted water and flies. As a result, they are moved away from the city. Fishery is taken up in Tung Khru, on the west of Bangkok, which has never been done before. In 2001, 28 rai was allocated for fish ponds. In the East, fish ponds are seen sporadically but the concentration is in the south and outside Bangkok. When fish food prices are high, farmers raise the fish naturally so there are only a few who raise them for export. Lawngrass nurseries are done by Muslim communities on the east side of Bangkok. There are fewer lawngrass nurseries in Minburi but there are more of them in Klong Sam Wa. This agricultural activity is approaching the city.

According to the site analysis of each agricultural activity, the agricultural activities on both sides of Bangkok are different, resulting in an urban invasion. The agricultural land on the west side consists of varied activities spreading out from the city center, and there are clusters of some activities for convenient product distribution. However, a certain activity needs a specific environment. A high potential activity such as orchid raising is grown from the inner city through the outer city. As for the east side of Bangkok, lawngrass nursery, a higher potential activity than rice growing, can move closer to the city. The agricultural activity on both sides which can penetrate the city from south to north is aquatic animal raising because the land is sinking. Growing fruit trees, once a popular and important agricultural activity, is no longer considered a career since it is not worth the investment. 


\section{Support of Suburban Agricultural Existence}

Financial support for each agricultural activity depends on the amount of land in rai per year. The amount of money based on the survey of income from the sale of production against the number of agriculturalists per duration per average amount of land is compared with the minimum income an agriculturalist can survive on without selling his land. It is found that those who raise orchids can earn 120,000 baht a person a year, ranked the most satisfactory, those who do lawngrass nurseries earn 104, 300 a person a year, which is ranked satisfactory, and those who grow other flowering plants earn 90,000 baht a person a year which is ranked unsatisfactory and who would like to sell their land. As a result, the target income, 100,000 baht a person a year, should be a standard. When compared with the income of each activity, the estimate which is lower than the standard is the amount of money to be supported as follows: kitchen vegetables / kaffir lime 12,222 baht per rai per year, screw pine 16,333 baht per rai per year, aquatic plants such as water-mimosa 25,000 baht per rai per year, fruit trees / oranges 16,571 baht per rai per year, fishery 20,333 baht per rai per year, flowering plants / White champaka, Crown flower and jasmine 3,333 baht per rai per year, vegetable farms 10,000 baht per rai per year, rice fields 1,666 baht per rai per year, and animal raising / cows 4,700 baht per rai per year. A point to notice is that an agricultural activity covering a large piece of land receives little financial support because after averaging the total area, the financial support is enough for agriculturalists. An activity fetching high income like orchids does not require financial aid.

\section{Discussion}

\section{Findings}

Points worth discussing are:

1. The Order and Factors Affecting the Existence of Each Activity

The most cited issues affecting suburban agriculture need solutions or support as follows:

- Economic factors such as the price of fertilizers, the price of energy and market expansion.

- Professional factors such as the bond between relatives, and the successor of younger farmers. In addition, it is found that the movement of agricultural labor in the suburbs results in the existence of agricultural activities especially rice fields because agricultural labor from outside works on a vacant piece of land. The movement can be divided into 3 types: 1) those who do farming in the same area. (They may do other activities along with farming.) 2) those who used to work in the city when they were young but have come back to do farming when they get older. 3) those who are from outside. They are younger people whose parents' land was divided among their brothers and sisters. And the plot of land is too small for them to do farming. Consequently, they rent a piece of land in the suburbs to grow plants such as rice which do not take long to harvest.

- Eco-environmental factors such as water pollution and a lack of water during summer. 
Figure 4: The three kinds of suburban farmers in dynamics

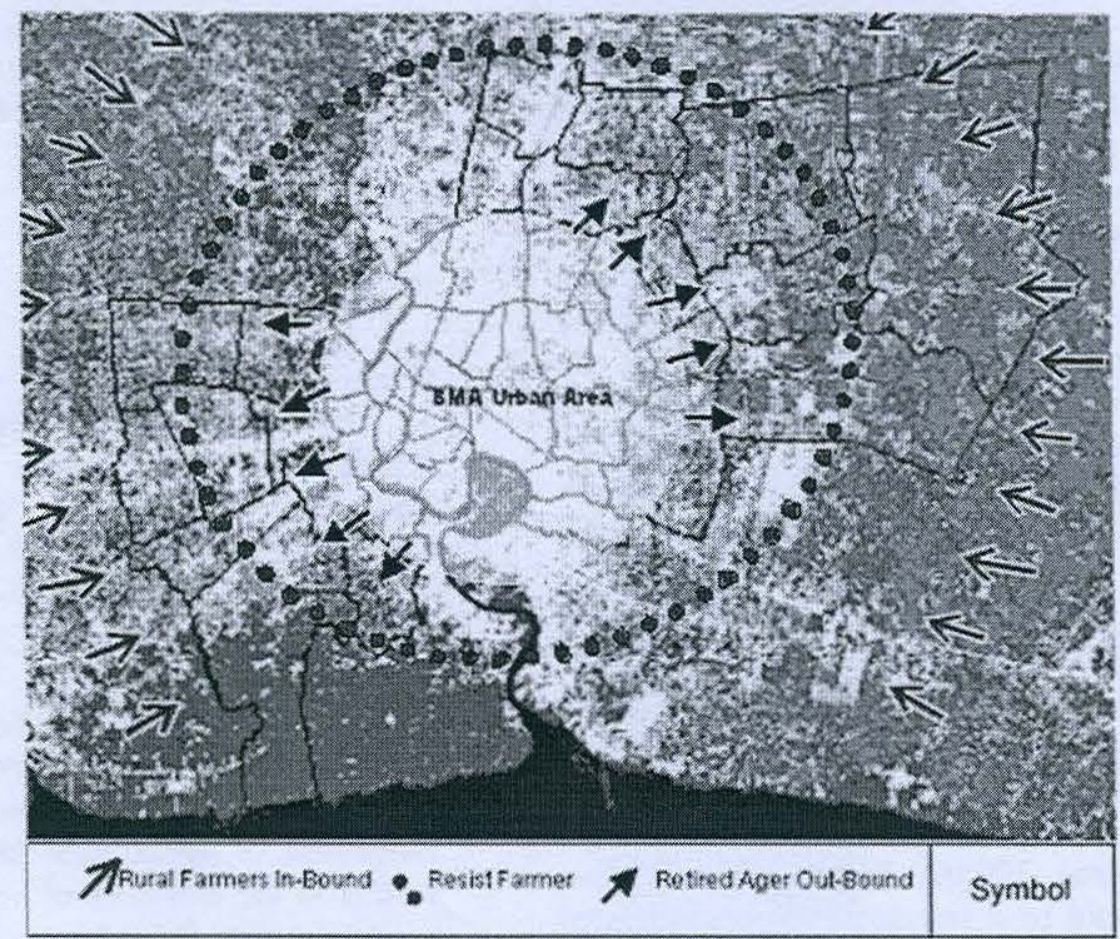

\section{Location and Movement}

The same agricultural activity is concentrated in one area for convenient distribution. There are many agricultural activities on the west side of Bangkok. An activity which shows remarkable retreat from the inner suburbs is vegetable farms. This movement causes agriculturalists to grow another kind of plant and to rent a new piece of land. This is not in line with the theory of Von Thunen: an agricultural activity requiring a lot of land will be away from the city (agriculture land use model / Least Cost Location Theory). It is also found that an intensive agricultural activity such as orchid raising will replace other activities especially along the route connecting an orchid nursery with a company exporting orchids. This finding does not match Von Thumen's agriculture land use model because orchids and other flowering plants are a growing business with a high return but there is no land which is close to the city for them to expand. Consequently, this activity has to be expanded unsystematically. 


\section{Existence and Succession of Agricultural Land around Bangkok}

Figure 5 : The direction of agricultural succession around Bangkok between 1988-2003

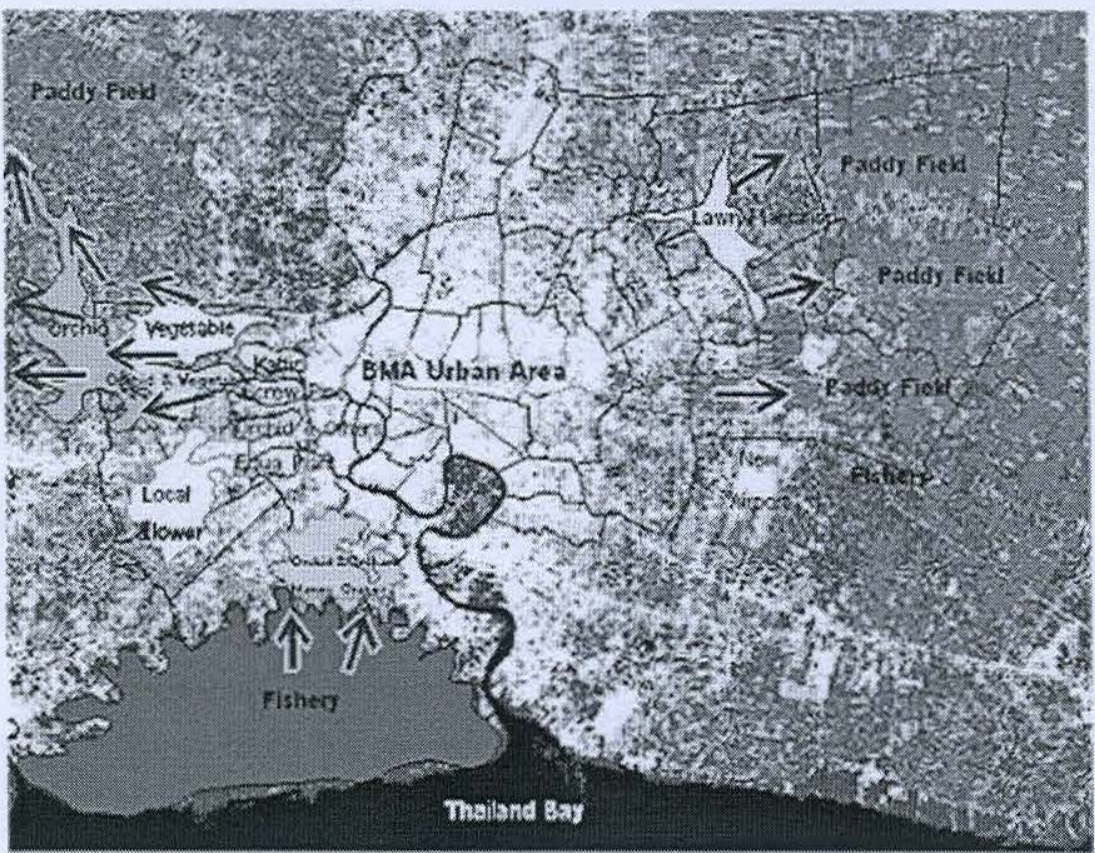

An activity which is moving closer to the city is aquatic animal raising in Thung Khru, Bang Mod, and Chom Thong because the land is sinking. Other agricultural activities cannot be done there. In addition, lawngrass nurseries are also approaching the city because they are more intensive than rice fields and use a smaller piece of land. This activity was taken up by a Muslim community which was far away from the city, so lawngrass nursery still has room to move closer to the city. This is in accordance with Von Thunen's agriculture landuse model despite their differences in details.

\section{Financial Support for Agriculturalists who Own the Land}

According to the field study, agriculturalists are satisfied with their income at a certain level and their income can be used to ask for compensation per rai per year for an agricultural activity. Since financial support cannot be applied to all, it can be used in an emergency, for conserved sites for such special fruit trees as lychee and Bang Mod oranges or for other measures such as land appropriation, buying the land back or renting the land for conservation such as enclosing the rest of the agricultural land. 


\section{Other Findings}

The field study reveals some suggestions supporting the existence of agricultural land surrounding Bangkok as follows:

\section{1) Agricultural location management}

New kinds of plants such as kaffir lime and orchids should be introduced on the east side. This land is close to the new airport so it is convenient for export.

2) Promotion of suburban agriculture In the suburbs there are few plant pests so there are various uses of land. Insecticide free fruit trees and vegetables should be promoted in addition to high-quality agricultural products for customers with high purchasing power.

\section{3) Utility development}

The bypass should be away from the living area to ease traffic problems. Canals and aqueducts should be properly maintained to be water sources and to carry agricultural products out of the farms. The water pumps used to prevent floods should be adapted to draw water to the farms during summer.

\section{4) Economics and financial compensation}

Compensation should be made when there are floods. A financial aid program should be launched to help farmers in semi-urban areas survive. In terms of policy, taxes on land should be collected at the same rate as the assessment of land for rent according to Henry George's guidelines. This will help reduce the purchase of a very large agricultural plot.

5) Plans for promoting urban quality of life Agricultural land with a good ecological system should be promoted as a recreational area and a center for city youth to carry out activities like parks in remote areas.

\section{6) Specific area intervention}

Agricultural intervention should be done in a limited area with high pressure such as Bang Ramad, Chom Thong and Saphan Sung by buying and land appropriation. As a result, integrated activities can be carried out in these areas leading to agricultural gardens later.

The agricultural land around major cities keeps changing and it faces serious problems such as speculation of land price so the land is left vacant; the growing number of housing projects so there is a reduction of the amount of agricultural land especially in specific growing locations which cannot be found in rural areas. The fewer these locations are, the more the urban communities' need for their quality of life and urban environment. The conservation of agricultural land can be done by allocating a proper location for each plant so that it can resist urbanization due to the economic, social and physical changes. To keep up with changes, this guideline has to be adjusted based on knowledge and experience.

\section{References}

Alonso, William. 1964. Location and Land Use : Toward a General Theory of Land Rent. Combridge: Harvard University Press.

Christopher R. Bryant and Thomas R.R. Johnston. 1992. Agriculture in the City's 
Countryside. Toronto: University of Toronto Press.

Furuseth, Owen J. 1983. The impact of local infrastructural and development policies on agricultural land alienation. Landscape Planning. Washington: USDA.

Hepner, George Franklin. 1979. A Directed Graph Approach to Rural Urban Fringe Land Use Conversion. Unpublished Doctoral Thesis, Arizona State University.

Higbee, E. 1967. Agricultural Land and the Urban Fringe. New York: Marrow.

Hiroyuki Nishimura. 1992. Agriculture in Urbanizing Areas : Conflicts and Ways Towards Harmony; Southeast Asian Countries and Japan. Dhaka: Centre on Integrates Rural Development for Asia and the Pacific (CIRDAP).

Hough Michael. 1995. Cities and Natural Process. New York: Routledge.

Khaisaeng Sukhawattana. 2002.

Bangkok and its region in early Rattanakosin era. Academic Seminar : Bangkok at the Year $220^{\text {th }}$ : Past and Future of Recent PP. 02/1-02/6.

Bangkok: Chulalongkorn University.

Sinclair, Robert. 1967. Von Thunen and urban sprawl. Annals of the Association of American Geographers. London: Blackwell Publishing.

Suthon Hinjiranan. 2002. Progress and Poverty / Henry George. Bangkok: Wattana Print.
Von Thunen, J.H. (1826). 1966. Der isolierte staat in beziehung auf landwirtschaft und nationlekonome. English translation: C.M. Wartenberg. Von Thunen's Isolated State. London: Pergamon. 